\title{
The Impact on Cayey, Puerto Rico of the Spanish American War: The Evolution of a Place Called Henry Barracks ${ }^{1,2}$
}

\author{
James J. Prewitt Diaz, Joseph 0. Prewitt Diaz \\ University of Puerto Rico, School of Law, Rio Piedras, Puerto Rico \\ Email: jprewittdiaz@gmail.com
}

How to cite this paper: Prewitt Diaz, J. J., \& Prewitt Diaz, J. O. (2016) The Impact on Cayey, Puerto Rico of the Spanish American War: The Evolution of a Place Called Henry Barracks. Advances in Historical Studies, 5, 183-205.

http://dx.doi.org/10.4236/ahs.2016.54016

Received: August 26, 2016

Accepted: September 18, 2016

Published: September 21, 2016

Copyright $(\odot 2016$ by authors and Scientific Research Publishing Inc. This work is licensed under the Creative Commons Attribution International License (CC BY 4.0).

http://creativecommons.org/licenses/by/4.0/ (c) (i) Open Access

\begin{abstract}
Introduction: This paper presents the results of a desk study of original documents on the impact of the development of a track of land for military use in Cayey, Puerto Rico. The paper is divided in four major segments: the Spanish Barracks (1897-1898), Camp Henry (1898-1909), The Cayey Naval Radio Station (1914-1932), and Henry Barracks Army Post (1910-1962). Desk Study: The investigators relied on interviews, pictures, and narratives of key informants that either lived, grew-up, or used the facilities of the Henry Barracks Army Reservation. This paper is a summary of approximately three thousand pages, pictures, and maps located in the National Archives and Records Administration (NARA) as well as documents from the Library of Congress of the United States and the Museo de Historia Militar, Madrid, Spain, and Army and Navy reports, general and specific orders, and Order of Battle documents archived in the libraries of the United States War College, Carlisle, PA., West Point Military Academy (New York) and the Naval Academy (Annapolis). Limitations: Most of the original materials such as logs, order of battle, and other original information was found in repositories in the United States, and dated from 1898 to 1967. A search of the Museo de Historia Militar in Madrid, Spain only had available information on the Spanish conquest of San Juan, and only rudimentary maps were found about the rest of the island of Puerto Rico. Summary of Findings: The study concludes the Spanish Government constructed a Barracks in Cayey in 1897. The Spanish troops remained in their Barracks until they were repatriated to Spain on October 18, 1898. The original reservation was set apart by Executive Order on July 7, 1903. An additional 372 acres were purchased in December 1903. The study concludes
\end{abstract}

\footnotetext{
${ }^{1}$ Henry Barracks Military Reservation was built in 1897 by the Spanish Army, and passed on the U.S. as part of the Spanish American War. It was declared excess land and closed in 1962.

${ }^{2}$ The authors acknowledge the contributions of Manuel Rivera (Manny), Harry Bennett, and Rafael Coca Navas to the completion of this work.
} 
that the geographical evolution of this land has had a marked impact in the development of the town of Cayey and the Central Mountain Region of Puerto Rico.

\section{Keywords}

Henry Barracks, El Cayey Navy Radio Station, University of Puerto Rico-Cayey, Municipality of Cayey

\section{Introduction}

The discovery of Cuba, Hispaniola (Haiti and Dominican Republic), and Puerto Rico in the latter part of the $15^{\text {th }}$ century, opened the doors to colonizing the south-eastern part of what is now Florida (a state in the United States) as well as Central and South America. Puerto Rico became a price holding for the Spanish armada, and the Galleons that transported riches from South America to Spain. Puerto Rico also served as a strategic defense/deterrent to protect Spanish interest in the Caribbean. San Juan, a small island in the north, remained the stronghold, where the Spanish Army settled its troops and built a fortification. The reminder of the island was protected by locally deployed Spanish Army elements who trained the insular support forces. One such post was located in Cayey, its primary role was to protect the crossroads between the four cardinal points of the island, as well as to provide an inland base where Spanish soldiers were sent to adjust to the tropical weather of the island.

This paper provides a historical overview of the role of the Henry Barracks Military Reservation in the development of the town of Cayey, Puerto Rico from 1898 to 1967. The paper describes the three main facilities in the Reservation: 1) the Spanish Fort, 2) Camp Henry (later renamed Henry Barracks), 3) Cayey Naval Radio Station. The paper presents a visual representation of how the Reservation changed and how changes in the structures are reflective of things to come.

Cayey is located in a valley in the central mountain range of the Island of Puerto Rico (Latitude: 18.1144, Longitude: 66.1681) ${ }^{3}$. It is located at the crossroads of major roads that permit travel and the flow of goods from the San Juan area in the north to Ponce, the second largest city, to the south. It is an entry point for the panoramic route that crosses the Central Mountain range and the catalytic point to some important events in the development of the Island.

By the $18^{\text {th }}$ century Cayey became a town ${ }^{4}$. The self-defense of the Puerto Rican

${ }^{3}$ Cayey sits on a plain surrounded by mountains, among which rise "El Torito" to an altitude of 720 meters above sea level. Its climate is cool and delightful, and its sanitary conditions are so good that under the Spanish rule there were built some splendid acclimatization barracks for the soldiers. The new barracks were called "Barracones de Henry" or Henry Barracks in honor of General Guy B. Henry. The lands of Cayey are very fertile and produce many varieties of fruits, but the principal sources of wealth are coffee and tobacco. The town is surrounded by a beautiful ravine in which there are springs that provide the inhabitants an abundant source of water. (Comments of Hon. Charles Hartzell (1903). Register of Porto Rico for 1903. San Juan, Puerto Rico: Press of Louis E. Tuzo.)

${ }^{4}$ Cayey was founded on August 17, 1773. 
people had begun as far back in 1642, when Para-military groups were organized in towns and villages as the island population grew. Field Marshal Alejandro O'Reilly was tasked in 1765 with the responsibility of organizing an urban militia ${ }^{5}$ in order to provide safety and security to the population as well as to augment the Spanish soldiers at the Garrison when needed. The rule remained that only Spanish soldiers would live in the Barracks established throughout the Island.

In 1887, there was a request from the Governor General D. Romulo Palacios to the Central Government in Spain to establish a military hospital. The intent was to provide a place for troops who had recently arrived from Spain to adjust to the climate and the tropical illnesses. A decision was made to construct a Spanish Barracks in Cayey for 250 men, a HQ component, and two Infantry Companies in 15 acres of land on a hill overlooking the town ${ }^{6}$. The proposed Barracks was to be composed of ten one-story buildings. The reason for selecting this site was threefold: the availability of raw materials locally ${ }^{7}$, low cost of workmanship, and the appropriateness of the climate. Construction began on 5 April $1897^{8}$.

The Barracks was occupied by recently arrived troops from Spain, who spent a time in Cayey getting acclimatized for service in the San Juan Fort (El Morro). In 1898 there were two Infantry companies (293 men) and about 47 soldiers working in the hospital. In addition there were 243 soldiers belonging to the Sixth Battalion of the Provisional Guard. All the personnel in the Barracks were Spanish, and responsible of the defense of the Guayama and Aibonito road in the event of an invasion.

\section{Preparing for the Defense of Cayey}

Julio Cervera Baviera, the commanding officer of the Engineers and Field Aide of General Macias was ordered to move the Sixth Battalion of the provisional guard from Cayey and a number of troops that had been transferred from Aibonito-a total of approximately 400 troops (see above the distribution of troops) - into a defensive position in the road from Guayama to Cayey. He set his Headquarters on the coffee plantation at the beginning of the narrows between Jajome and Guamani. The objective was to defend the Alfonso XII bridge (see photograph in Figure 1).

The Spanish forces set themselves up in the higher ground of the straits and at the sides of the Guamani Ridge. The Spanish forces were ordered to delay or stop the advance of the American forces from heavily defended terrain.

${ }^{5}$ In 1765 he was appointed marshal and traveled to Puerto Rico with a mission to be loyal to Spain that protected the island from possible invasion militia. O'Reilly formed a professional and highly disciplined militia, so he is remembered on the island as "father of the Puerto Rican militia."

www.biografiasyvidas.com/biografia/o/o_reilly.htm. Accessed from Internet on July 3, 2014.

${ }^{6}$ The land was purchased from Francisco Fernandez Navas.

${ }^{7}$ The blocks came from the furnace of Mr. Manuel Nuñez Romeu, the raw material for the blocks from the property of Mr. Jose Benito Dumont, and the wood were gathered from the forest around Cayey and molded for use by Mr. Jose V. Philemon.

${ }^{8}$ Letter written by Mr. Vicente Rodriguez, the mayor of Cayey, to the Captain General of Puerto Rico dated 5 April 1897.

${ }^{9}$ Lopez, P. (1972). La historia de Cayey. Cayey, Puerto Rico: Departamento de Humanidades. Colegio Universitario de Cayey. pp. 70-71. 


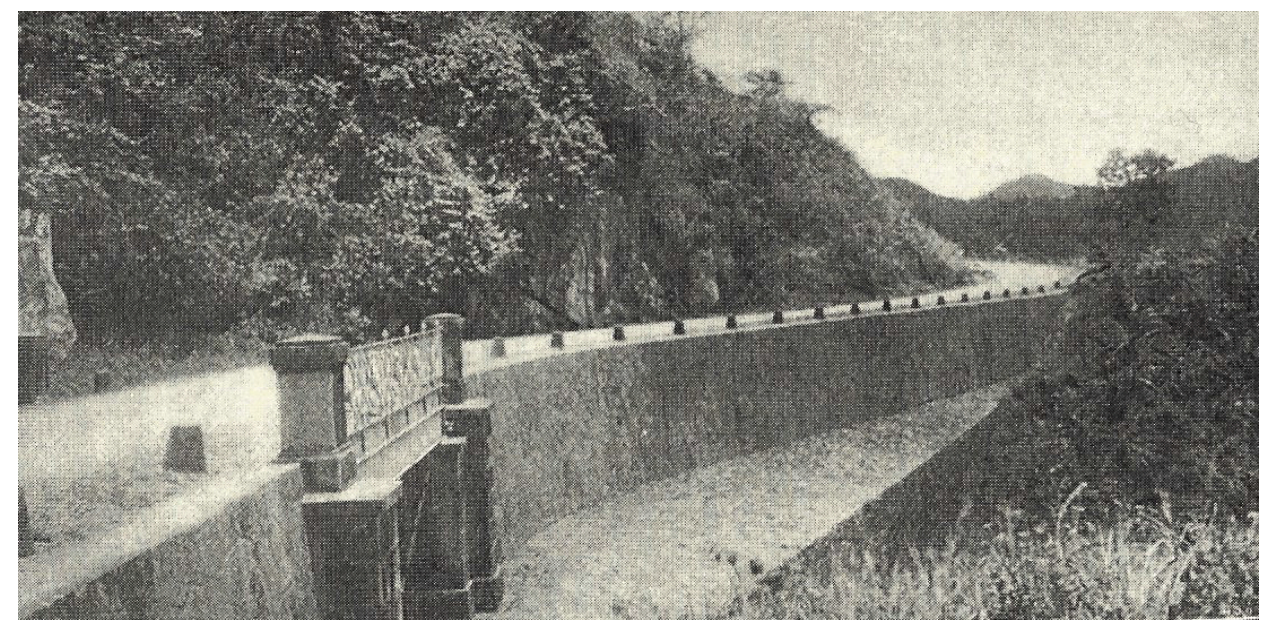

Figure 1. Alfonso XII Bridge, Site of the initial contact between Spanish and American Armies. (Hartzell, 1903). Register of Porto Rico for 1903. San Juan: Press of Louis E. Tuzo and Co. P. 192).

\section{The American Forces March unto Cayey}

In 1898, the Spanish American war brought the U.S. Army to Puerto Rico. The American force was organized into four columns (see Figure 2). General Brooke and his troops landed in Arroyo on August 1, $1898^{10}$. The objective of the column was to advance to the capital San Juan through the center of the island from Arroyo through Cayey, thus over powering all Spanish Army resistance and capture the strategic crossroads located in Cayey.

The columns of American Expeditionary soldiers move from Arroyo to Guayama and onto Cayey. These forces were members of the State Guard from Ohio and Pennsylvania ${ }^{11}$.

In the meantime, lead elements of, the $4^{\text {th }}$ Ohio and the $3^{\text {rd }}$ Illinois under the command of Gen. Brooke scouted the routes leading from Guayama to Cayey. These elements collided with elements of the Spanish Army near a bridge at the Guamani strait. The scrimmage lasted all day. The Spanish troops took positions along the hilltop and met the Americans with accurate rifle fire resulting in five American Soldiers wounded $^{12}$. American forces maneuvered around the Spanish positions and by doing so, nullified enemy resistance along this route. The road from Guayama to Cayey was cleared $^{13,14}$. The exchange of fire between the Spanish and the Americans resulted in three American soldiers and several Spanish troops injured. General Brooke's soldiers captured the Spanish "Cuartel" in the town of Cayey on August 8, 1898, in route to an attack on the capital San Juan.

\footnotetext{
${ }^{10}$ Darrach, J. M. (1898). Descriptive account of the operations and skirmishes about Guayama, Puerto Rico. Harper's Weekly, Vol. XLIL(2179), 942.

${ }^{11}$ (Source: Emerson, K. (2011). Maps of the Spanish American War. Puerto Rico, 1898. Puerto Rico Expedition, operations 25 July-12 ${ }^{\text {th }}$ August 1898. (www.emersonkent.com).

${ }^{12}$ Muwsicant, I. (1998). Empire by default. New York: Henry Holt \& Co. Pp. 535-536.

${ }^{13}$ Ibid. Darrach op cit.

${ }^{14}$ Trask, D.F. (1981). The war with Spain in 1898. New York: MacMillan Publishing C. Inc. (page 339).
} 


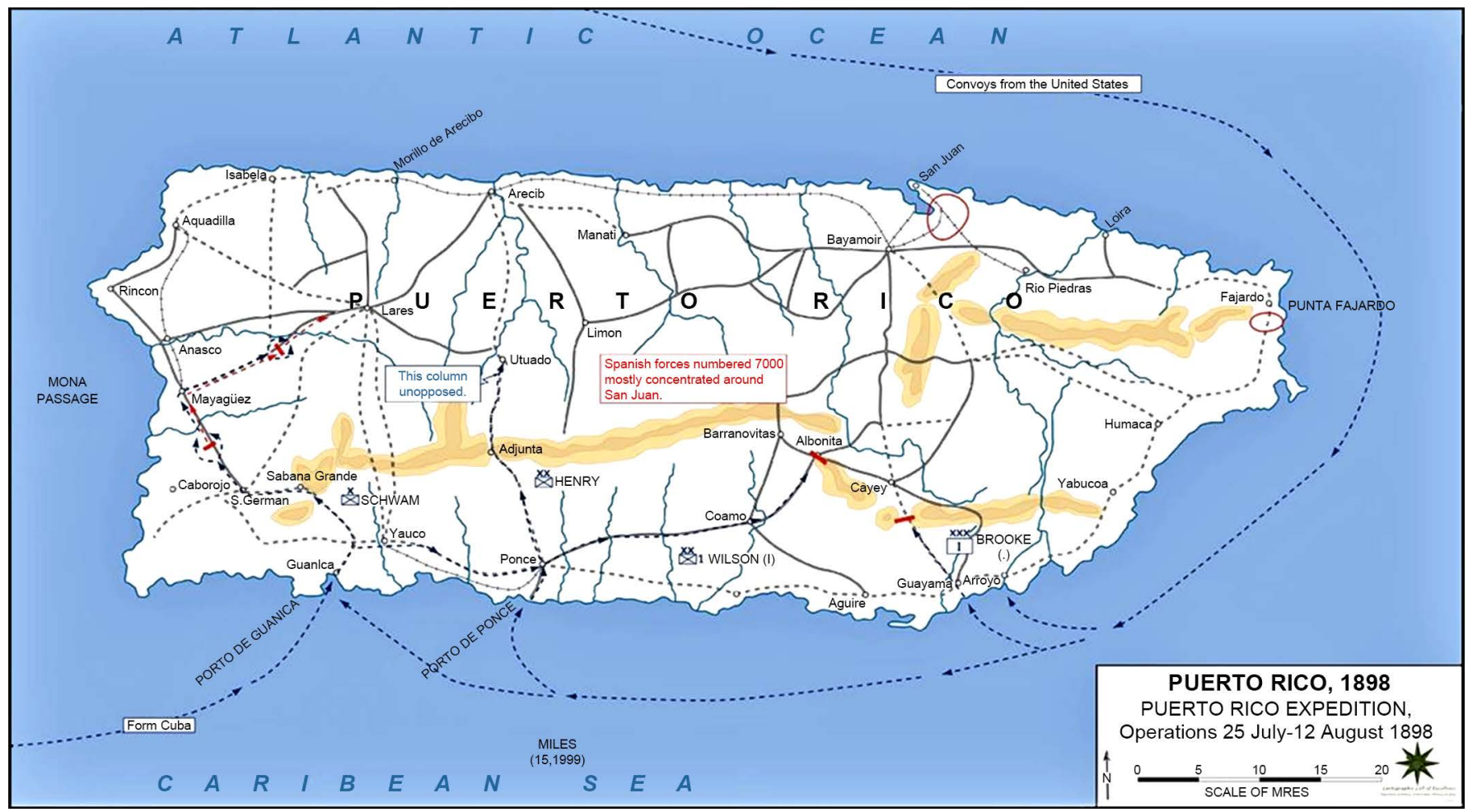

Figure 2. U.S. Army invasion routes and battle lines, 1898 (Post Source: Emerson, K. (2011). Maps of the Spanish American War. Puerto Rico, 1898. Puerto Rico Expedition, operations 25 July-12 th August 1898. (www.emersonkent.com).

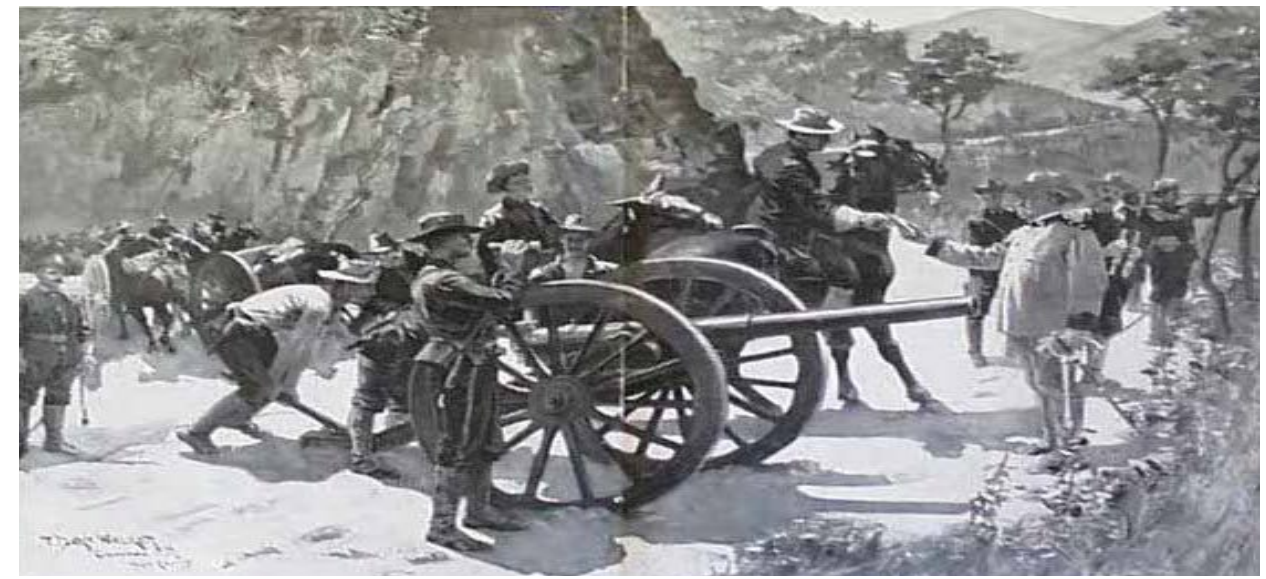

Figure 3. Drawing of General Brooke about to attack the Spanish Barracks in Cayey on August $8^{\text {th }}, 1898$ when he receives a message from General Henry ordering the cessation of hostilities. (Source: The Harpers Ferry (September 24. 1898). "The Dramatic Ending of the War in Puerto Rico”. Accessed from Teddy Roosevelt-Rare Newspapers.com. July 3, 2014.

The morning of the $8^{\text {th }}$ of August the valley of Cayey woke up to an impressive military display. General Brooke had positioned three batteries of artillery (Battery B, Pennsylvania, Battery A Missouri Artillery, and the $27^{\text {th }}$ Indiana Artillery) on the hills from the Guayama road overlooking the town. Figure 3 above shows the cessation of hostilities shortly before the beginning of the attack on Cayey 
He then proceeded to the Cuartel Español (the Spanish Barracks) with two Calvary troops from the $6^{\text {th }}$ U.S. Calvary, Troop H, and Pennsylvania Volunteer Calvary ${ }^{15}$. There was no resistance offered by the Spanish Army and by noontime on that day General Brooke sends a message to the War Department: "Cayey taken”.

\section{The Spanish Barracks (Cuartel Español) Becomes Camp Henry16}

As a result of the treaty of Paris signed the 18 August 1898, Puerto Rico, Cuba and the Philippines were ceded to the United States as spoils of war. The Spanish empire had collapsed. The Spanish soldiers returned to their barracks in Cayey. They remained in quarters until they were repatriated to Spain on 15 October $1898^{17}$.

This captured piece of real estate consisted of 15 acres of land on a hill east of the town of Cayey. It overlooked the entrance of the town of Cayey and thus controlling the strategic cross-roads from Caguas, Guayama, Salinas, and Aibonito. From that vantage point all activities of the town were monitored. The main building in the installation was 320 feet by 30 feet and was the largest building in the region. It housed the Surgeon General, Officers, and a 112-bed hospital (see Figure 4).

The largest building (Hospital) was located at the top of the hill, known as Hospital Hill (La Loma del Hospitalillo) by the locals ${ }^{18}$. Northeast of the hospital was the kitchen and a squad room with a capacity of 20 men (probably cooks and orderlies). Just below the top plaza was a Quartermaster stables with a capacity for 78 animals and a wagon shed with capacity of 20 wagons. Three smaller buildings in the same area accommodated the following: 1) the plumbers and a tin smith; 2) the QM barracks with a capacity for 17 men; 3) QM store house; 4) QM shops (26); 5) an oil house with a capacity of 5000 gallons. On the access road from the Hospital there were two wooden quarters that accommodated NCOs and two cavalry companies. At the bottom of the hill was the Headquarters and guardhouse ${ }^{19}$. In 1899, the San Cipriano hurricane destroyed the barracks. A new hospital was built on the bricks of the Spanish hospital. The American forces used the remnants of the Spanish Barracks after the 1889 Hurricane, and rebuilt ten wooden structures using the blocks and rocks from the quarry on the Post. The American soldiers were repatriated in 1901 . The $2^{\text {nd }}$ Battalion of the Puerto Rico Volunteer Infantry took over the Barracks on 23 February $1901^{20}$. There were four companies (E, F, G, and H) assigned to Camp Henry (two infantry and two mounted).

\section{The El Cayey Naval Radio Station (1912-1932)}

In 1914 the Secretary of the Navy had planned to establish a high power station in

\footnotetext{
${ }^{15}$ Ibid. Darrach op cit.

${ }^{16}$ The description offered were derived by a Map entitled, "Map showing boundary lines of the original Spanish Reservation and the present reservation as described General Order \# 97 War Department July 7, 1903".

${ }^{17}$ Lopez, p. 71.

${ }^{18}$ Description of buildings-Spanish Barracks, Cayey, Porto Rico. G.O. 97 War Department-July 7, 1903.

${ }^{19}$ This description is on a map compiled and corrected from existing maps. By Maj. H.C. Price and Lt. Carlos M. Lopez of the Puerto Rico Regular Infantry, April 27, 1915. NARA Map Collection.

${ }^{20}$ On March 2, 1899, the Puerto Rico Regiment of Volunteer Infantry was organized. One battalion was stationed in San Juan while a second one stood guard at Henry Barracks.
} 


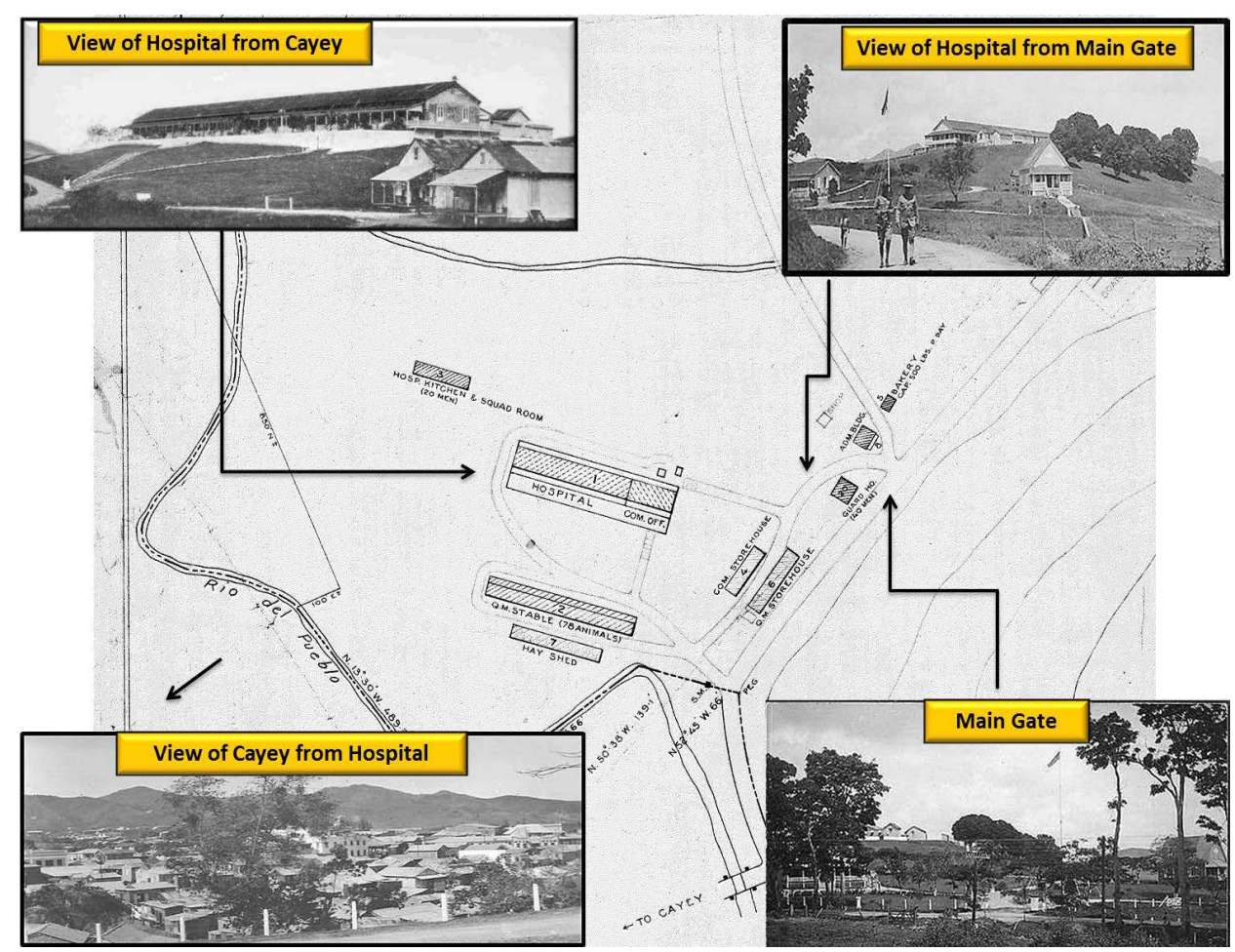

Figure 4. Camp Henry, Cayey, Puerto Rico Circa 1903. (Duncan, 1910). Post and Reservation Map of Henry Barracks, P.R. Library of Congress. G-30-11-2-Mil Sta-PR.

Cayey. Because of this decision, the southern side of the Henry Barracks Reservation was surveyed and chosen by the U.S. Navy for the establishment of a radio communication base. Cayey became one of five radio communication stations in the world (others were Cordova, Alaska, Arlington, VA, Cavite and Tutuila in Guam, and Pearl Harbor in Hawaii) that formed the most powerful chain of communications for the United States ${ }^{21}$.

In 1915 the Secretary of War had begun negotiations to transfer a track of land from the War Department to the US Navy ${ }^{22}$. In August 29, 1916 the War Department transferred a track of land from the Henry Barracks Reservation to the Navy Department by authority contained in the Naval Appropriations Act (39 Stat. Law 568). The Naval Reservation at Cayey Puerto Rico comprised 59 acres of land known as Magazine Hill transferred to the Navy in $1916^{23}$.

On December 18, 1916 the White House approved the transfer of $\$ 400,000$ for the

\footnotetext{
${ }^{21}$ For further reading see: Hooper, S. C. (1922). Developments in high-power radio and its applications in the services of the United States Navy. Radio Broadcasters Magazine. 1 (3) 484-489. The Army was authorized to use the Navy generated electrical energy to use in lighting of Henry Barracks, not to exceed $600 \mathrm{kH}$ per month.

${ }^{22}$ Letter from the Secretary of War dated August 26, 1915. NARA 12479-424: 15.

${ }^{23}$ Draft Clause for approval from the $64^{\text {th }}$ Congress to be incorporated in the Navy Bill. The following described part of the military reservation of Henry Barracks, Cayey Puerto Rico is hereby transferred to and placed under the jurisdiction of the Navy Department for use for Naval Purposes. "The part of the military reservation of Henry Barracks knows as magazine hill, comprising that portion of said reservation lying westerly of Quebrada Las Lleras and south and east of the Caguas and Guayama Roads. NARA 12479-424: 6.
} 
construction of a protected High Power Radio Station in Cayey. The justification for this expenditure read "The island of Porto Rico is of extreme strategic importance in connection with fleet operations, due to its location. With a High Power Radio Station would ensure communication with the fleet, Europe, and South America to a greater degree than by any other means." ${ }^{24}$ Figure 5 shows a map of the Naval Station with its three large towers and quarters for officers and enlisted men.

Congress approved a high power radio station ${ }^{25}$. The Naval Appropriation Committee disbursed the already approved $\$ 400,000$ for the establishment of the radio station. The Secretary of the Navy reported for both in 1918 (Serial Set Volume 7495, House Document 1450, page 529), and in 1919 (Serial Set Volume 7703, House Document 729, page 357) for the construction of the High Power Radio station in Cayey. Three 620-foot towers of steel were constructed. On February 5, 1920 the High Power Radio Station was placed in commission ${ }^{26}$. In addition the following projects were developed at the Cayey Radio Station: 1) established a distant control for the Station, 2) moved one generator from Cavite in the Philippines to install in Cayey, and 3) enlarged the water supply for engine cooling purposes at an additional cost of $\$ 104,000^{27}$. The photo below shows the Cayey Radio Station in full operation. The Radio Station was run by General Electric High Compression Oil Engines (Type GM-52) ${ }^{28}$. On August 16, 1920, there was approval for additional work on the Radio Station. These included walks, sanitary facilities, hurricane doors and windows, and connection of the three engine driven generator foundations together with concrete to eliminate vibration ${ }^{29}$.

These personnel were moved to San Juan as a result of the Hurricane of 1928. They were never to return on a permanent basis to $\mathrm{Cayey}^{30}$, but rather would travel to the radio station as needed. The U.S. Army took over the care and protection of the Base.

The municipality of Cayey was looking at Magazine Hill (identified in Spanish language as "El Polvorin" (see Figure 6 and Figure 7) for expansion of the town and construction of a hospital. The municipality requested that the U.S. Government return Magazine Hill to the town since they had learned that it would not be used by the $\mathrm{Navy}^{31}$. Magazine Hill was transferred to the municipality of Cayey on March 5, $1923^{32}$.

\footnotetext{
${ }^{24}$ Letter from Josephus Daniels, Secretary of Navy to the Secretary of Treasury (Dec. 18, 1916). NARA-28677: 26.

${ }^{25}$ Public Law \# 64-391, approved Mar 4, 1917. Congressional Records. NARA.

${ }^{26}$ Radiogram to the Secretary of the Navy. NARA 12479-424: 21.

${ }^{27}$ Budget submitted by the Bureau of Steam Engineering to the Secretary of the Navy (July 14, 1919). NARA 432010-914-W

${ }^{28}$ Letter from the Commandant of the Navy Yard in New York City to the Chief of the Bureau of Engineering (January 15, 1923). NARA 12479-424:32.

${ }^{29}$ Outline of radio work for the fiscal year 1921 in US Naval Radio El Cayey. dated August 16, 1920. NARA: 464310-604-W-K 10.

${ }^{30}$ Letter from Chief of Naval Operations to the Chief of the Bureau of Navigation, June 15, 1922. NARA 12479-424: 24.

${ }^{31}$ On June 2, 1922, the Municipal Assembly of the City of Cayey adopted a resolution "requesting the transfer in favor of the Municipality of Cayey the Magazine Hill (59 Acres) for the construction of a Hospital to handle general medicine and surgery". NARA 12479-424: 27 P.

${ }^{32}$ Executive Order \#3806 Ordering the return of Magazine Hill to the Municipality of Cayey, (March 5, 1923). NARA-12479-424: 27-3 P.
} 


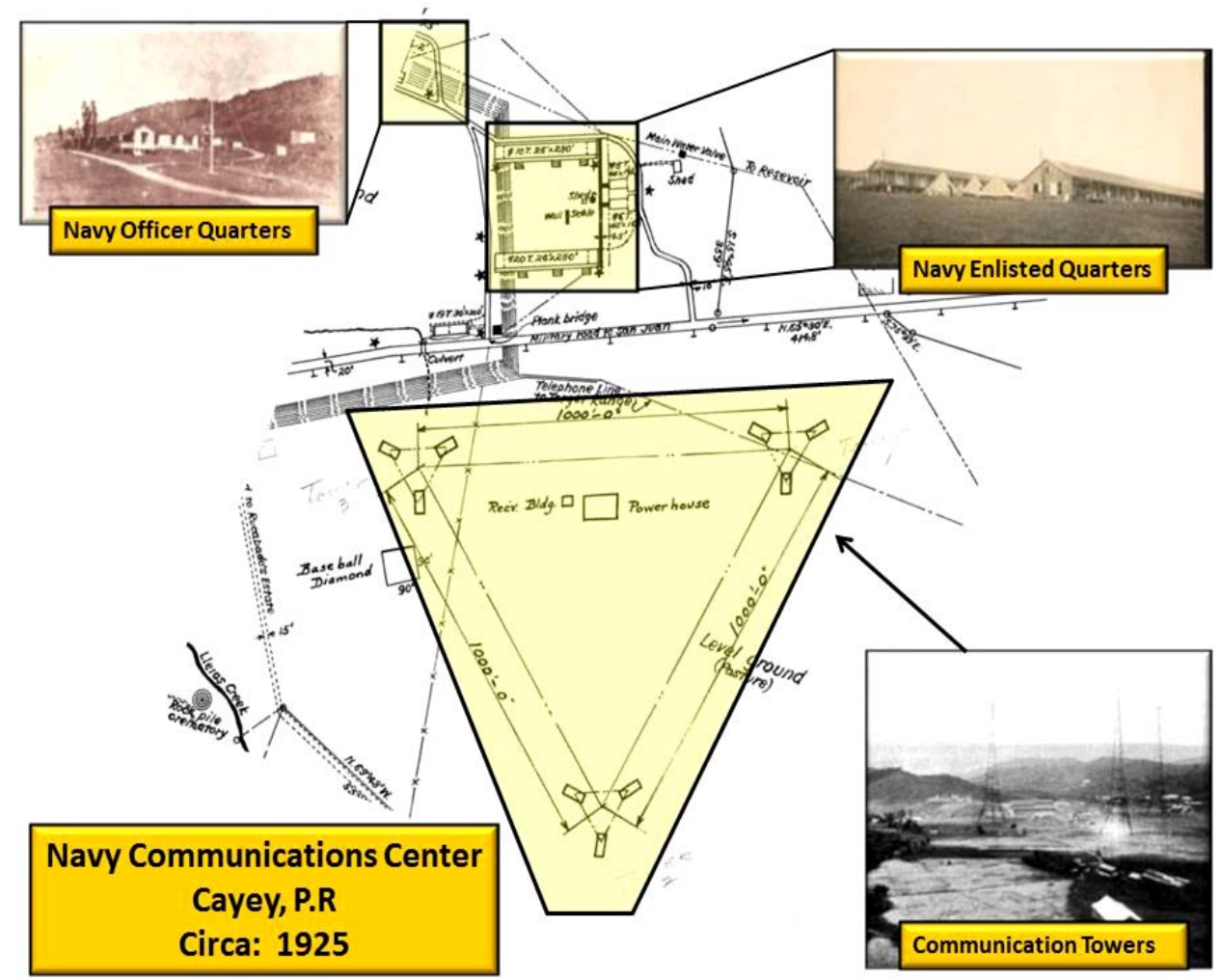

Figure 5. Cayey Naval Station (1925). The map and photos were obtained from NARA-28677: 470 .

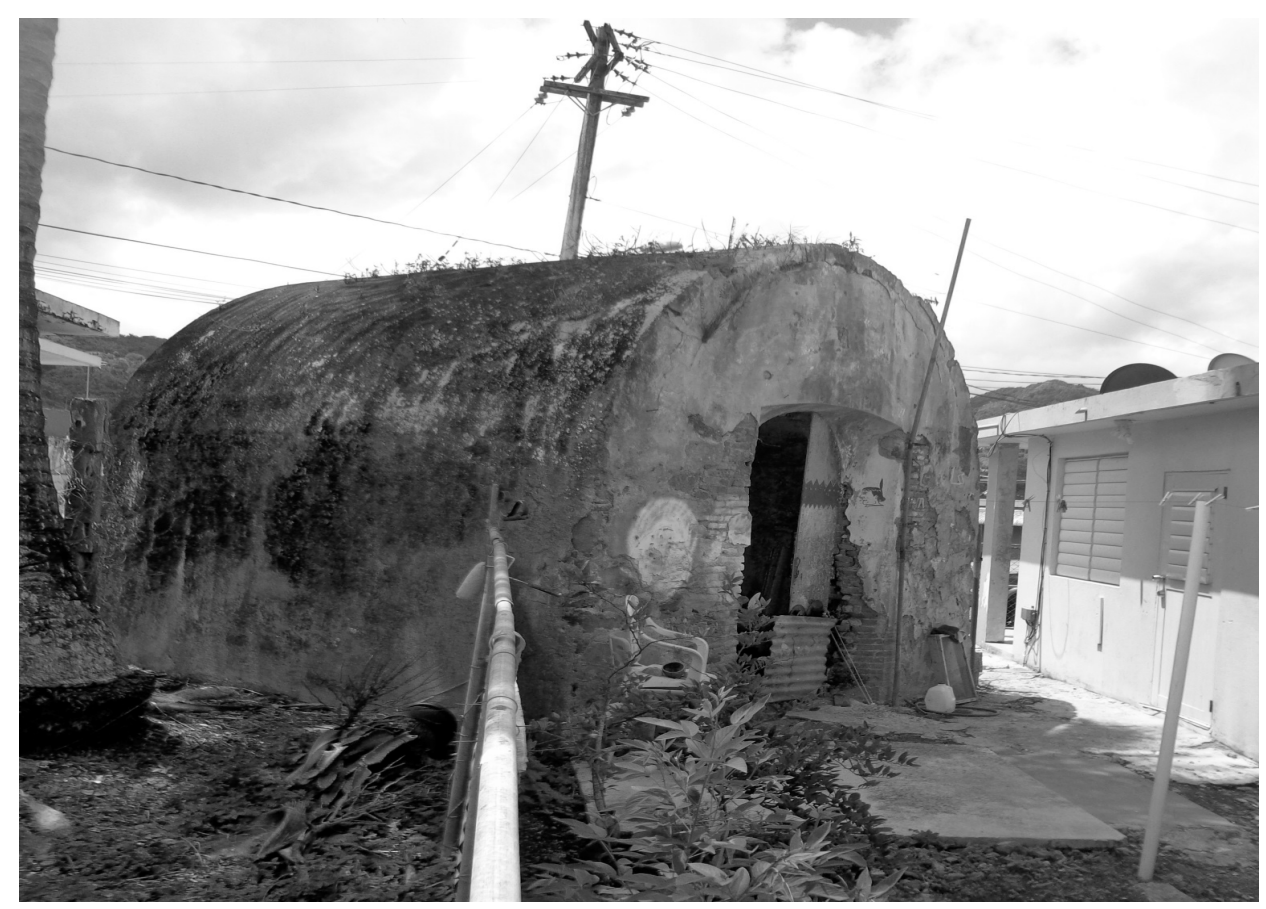

Figure 6. Present day reminisce of the Spanish Army ordinance magazine. (Photo courtesy of the Harry Benet Collection). 


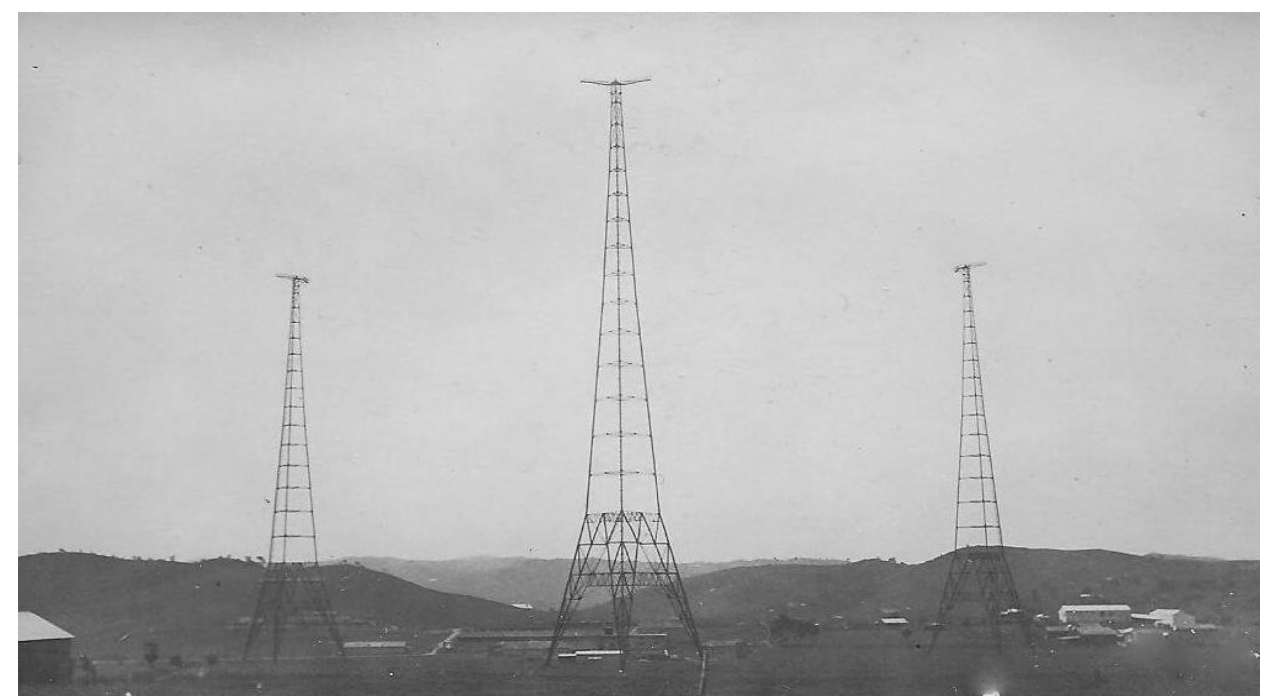

Figure 7. Communication Towers at the Cayey Naval Station. (Source: Hooper (1922) Developments in high-power radio and its applications in the services of the U.S. Navy. Radio Broadcasting Magazine 1(3), 484-489.)

In 1918 the base was fully operational with 25 men per shift working three shifts. The station was used exclusively for receiving messages for the Commander for the Caribbean Fleet. The station received 5000 words daily ${ }^{33}$. Figure 7 shows the Powers of the Navy Station.

At Puerto Rico, the Greenland Plan ${ }^{34}$ called for development of a major operating base as the keystone of the Caribbean defense, with facilities to include a thoroughly protected anchorage, a major air station, and an industrial establishment capable of supporting a large portion of the fleet under war conditions.

Puerto Rico was to be the "Pearl Harbor of the Caribbean", furnishing logistic support to outlying secondary air bases developed on Antigua, St. Thomas, and Culebra ${ }^{35}$. WW2 was just around the corner, and this required yet another adjustment to the Henry Barracks Military Reservation. The Navy Station was closed down, the towers dismantled, and the lands in the southern part of the Reservation were taken over by an Army that was preparing for war. Figure 8 presents the destruction of the last tower. By 1938 the El Cayey Radio Station was closed, and the towers were transferred to Isla Grande in San Juan where the high power radio station would be nearer the Command of the Fleet.

\section{The Henry Barracks Army Post ${ }^{36}$}

The life of Henry Barracks Army Post is intertwined with the life of the Puerto Rican

\footnotetext{
${ }^{33} \mathrm{At}$ the control room there were teams of operators that worked 24 hours a day in three shifts. They each worked in individual receiving posts. Recieving up to 5,000 words in Morse code during the 24 hour period.

${ }^{34}$ The Framework of Hemisphere Defense, Chapter 1, page 10. Accessed from Internet on 17 July 2014 from http://www.history.army.mil/books/wwii/Guard-US/ch1.htm.

${ }^{35}$ US Department of the Navy (1940). Building the Navy's Bases in World War II. Washington D.C.: U.S. Government Printing Service. Vol 1., Chapter 18, page 5.

${ }^{36}$ Parsons (2010). Henry Barracks Military Reservation-Cayey, Puerto Rico. Norcross, Georgia. U.S. Army Corps of Engineers. (p.2-1 to p2-3).
} 


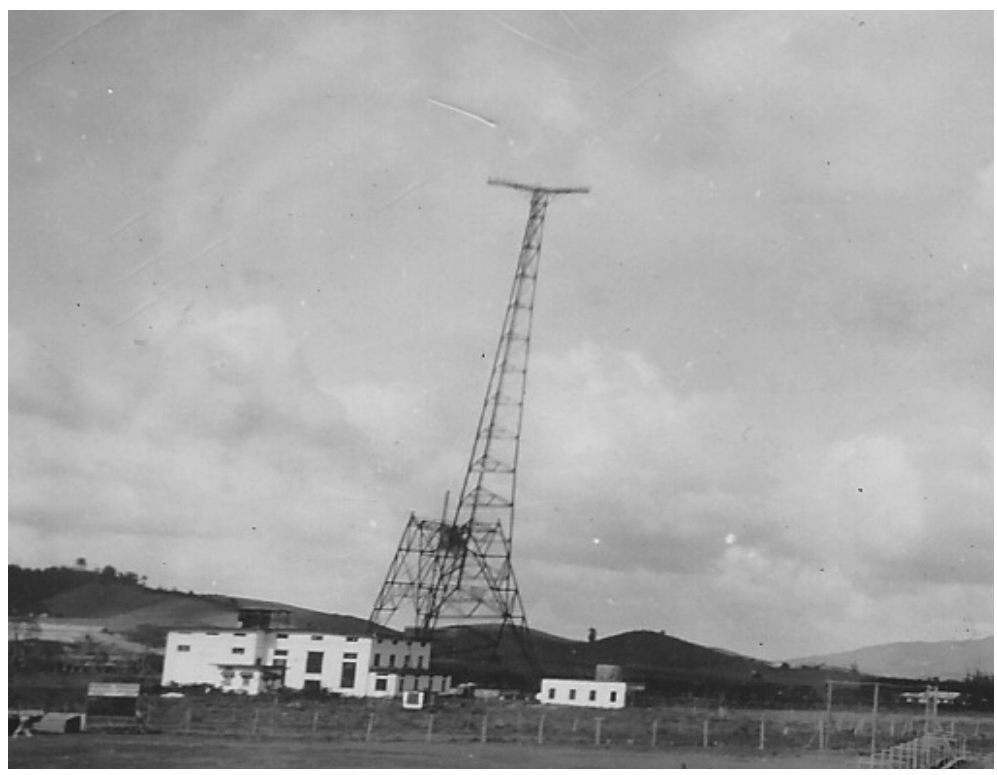

Figure 8. Destruction of the last tower (Photo courtesy of the SGT Joe C. Prewitt collection).

soldiers that served in the Puerto Rico Infantry Regiment and the weather. Puerto Rican men wanted to serve in the military for two reasons: 1 ) as a way to provide for their family with a steady income, and 2) the prestige of being a cut above other men in the society. As long as there was a need to accommodate the soldiers, there was a role for the Post $^{37}$. The weather played an important role on the evolution of the Post and the construction of permanent structures. For example three hurricanes-San Ciriaco in 1899, San Felipe in 1928, and San Ciprian in 1932-had a major impact on the physical development of the Henry Barracks Army Post. Another important factor was the deployment of the $65^{\text {th }}$ Infantry to assist in several little known campaigns in Central America called Banana wars ${ }^{38}$. Thus the Henry Barracks served as a training post for the Marines and other Army units with a skeleton crew in the Barracks.

In October 1898, with the creation of the American Military Government, the Military Department of Puerto Rico assumed control of Insular Military Affairs, and Cayey became one of the twelve posts that remained from the Spanish Government. On February 23, 1901, American troops were relieved from their duties in occupation of former military lands, and they repatriated to the United States. The $2^{\text {nd }}$ Battalion of the Puerto Rico Provisional Regiment of Infantry ${ }^{39}$ was housed in Cayey under the command of Major R.F. Ames.

The U.S. Army inherited from the Spanish Army all the buildings in Hospital Hill: 1) a Barrack size structure ( $30 \mathrm{ft}$ by $320 \mathrm{ft}$ ) built in 1899 used as a hospital and officers'

\footnotetext{
${ }^{37}$ Since the Department of War took over the management of the land of the Spanish Barracks, there were discussions about the value of maintaining an Infantry Battalion in Cayey. The argument was that the Post was far away from easy access to transportation and could not rapidly deploy. It was not until 1939 that Henry Barracks was recognized as an Army Post.

${ }^{38}$ Langley, L. D. (1983). United States Intervention in the Caribbean 1898-1934. Delaware: Scholarly Resources, Inc.

${ }^{39}$ Hartzell, C. (1903). Register of Porto Rico 1903. San Juan, P.R.: Press of Louis E. Tuzo.
} 
quarters; 2) the quartermasters' stables erected in 1899; the 3) Hospital kitchen and squad room; and 4) an assortment of QM storehouses, a bakery, and a commissary. The custody of the post in Cayey was placed under the jurisdiction of the Second Battalion of Puerto Rican Regiment US Volunteers-Mounted Battalion ${ }^{40,41}$. In 1899, hurricane San Cipriano destroyed all the buildings of the former Spanish Barracks, now Camp Henry.

In 1901 two large barracks, the Officers' Quarters, and the Post Exchange were erected. They were made of wood and had galvanized iron roofs. A guard House was erected in 1902 made of wood and a galvanized steel roof. In 1905 NCO Quarters were erected all wooden throughout and with galvanized steel roofs. In the same year, President Theodore Roosevelt made an Inspection visit to Camp Henry as depicted in Figure 9, taken with the President in the Hospital stairs of the Spanish Fort.

In 1908, the Porto Rico Provisional Regiment of Infantry was redesigned on 30 June as the Puerto Rico Regiment of Infantry and allotted to the Regular Army. The $2^{\text {nd }}$ Battalion was in Cayey.

Two companies from the $2^{\text {nd }}$ Battalion were deployed to the Canal Zone in $1917^{42}$. The assessment of the Battalion Commander at the time of deployment was that "except for one building everything else would have to be rebuilt" ${ }^{34}$. Henry Barracks is situated in the center of the island. It is thirty-seven miles from the nearest coast, and all supplies of every kind had to be transported at a high cost over mountain roads by mule teams or trucks. The transport of freight and passengers was at great expense ${ }^{44}$. Henry Barracks was not the preferred spot for an Infantry regiment.

\footnotetext{
${ }^{40}$ On May 20,1899, Brigadier General George W. Davis, US Volunteers, who had succeeded General Henry in command of the Department, published General Order, No. 65, "Headquarters Department of Porto Rico", series of 1899, for the formation of the Battalion and designation of the companies as A,B,C, and D, fixing the enlisted strength to 100 men each. On February 12, 1900, General Davis issued General Order No 34, "Headquarters Department of Porto Rico", series of 1900, directing that under instructions from the President of the United States, through the Secretary of War, a Mounted Battalion of Porto Ricans, be organized. The order prescribed that the battalion should consist of four companies designated E, F, G, and H, to be the Mounted Battalion of the "Porto Rican Regiment". On February 20, 1900, "Headquarters Department of Porto Rico" issued General Order No. 38, prescribing that the two Battalions of native troops should be known as the "Porto Rican Regiment US Volunteers". The mounted Battalion was to be stationed at Camp Henry, Post of Cayey. (Accessed on July 7, 2014 from: http://www.valerosos.com/65thpg1.htm).

${ }^{41}$ US Army Center of Military History. (12 March 2010). Linage and Honors: $65^{\text {th }}$ Infantry Regiment (The Bonriqueneers). Assessed on July 7, 2014 in

http://www.history.army.mil/html/forcestruc/lienages/branches/inf/oo65in.htm

${ }^{42}$ See Letter from Brig Gen. R.N. Christsum, Commanding General, Camp Las Casas dated January 27, 1919. In this letter he presents the misgivings of Henry Barracks as a Military installation and indicates that some construction will have to happen before the troops arrive from the Canal Zone, since Hurricane San Ciprian had destroyed one of the Company size structures.

${ }^{43}$ On April 6, 1917 Germany continued the submarine warfare, and this was perceived as an act of war. The Porto Rico House of Delegates sent a message to President Wilson expressing their solidarity and offering "absolute solidarity of the people of Puerto Rico" backed up with a request to enlarge The Porto Rico Volunteer Infantry Regiment. While not immediately approved, if was soon realized by the War Department that these soldiers may serve as substitutes for the regular soldiers in American Units that would be released to fight in Europe (Knock, 1992). To end all wars: Woodrow Wilson and the quest for a new world order. Princeton, New Jersey: Princeton University Press.

${ }^{44}$ Report from the Inspecting Officer with a recommendation of maintaining the troop in the San Juan area with its Headquarters in Las Casas.
} 


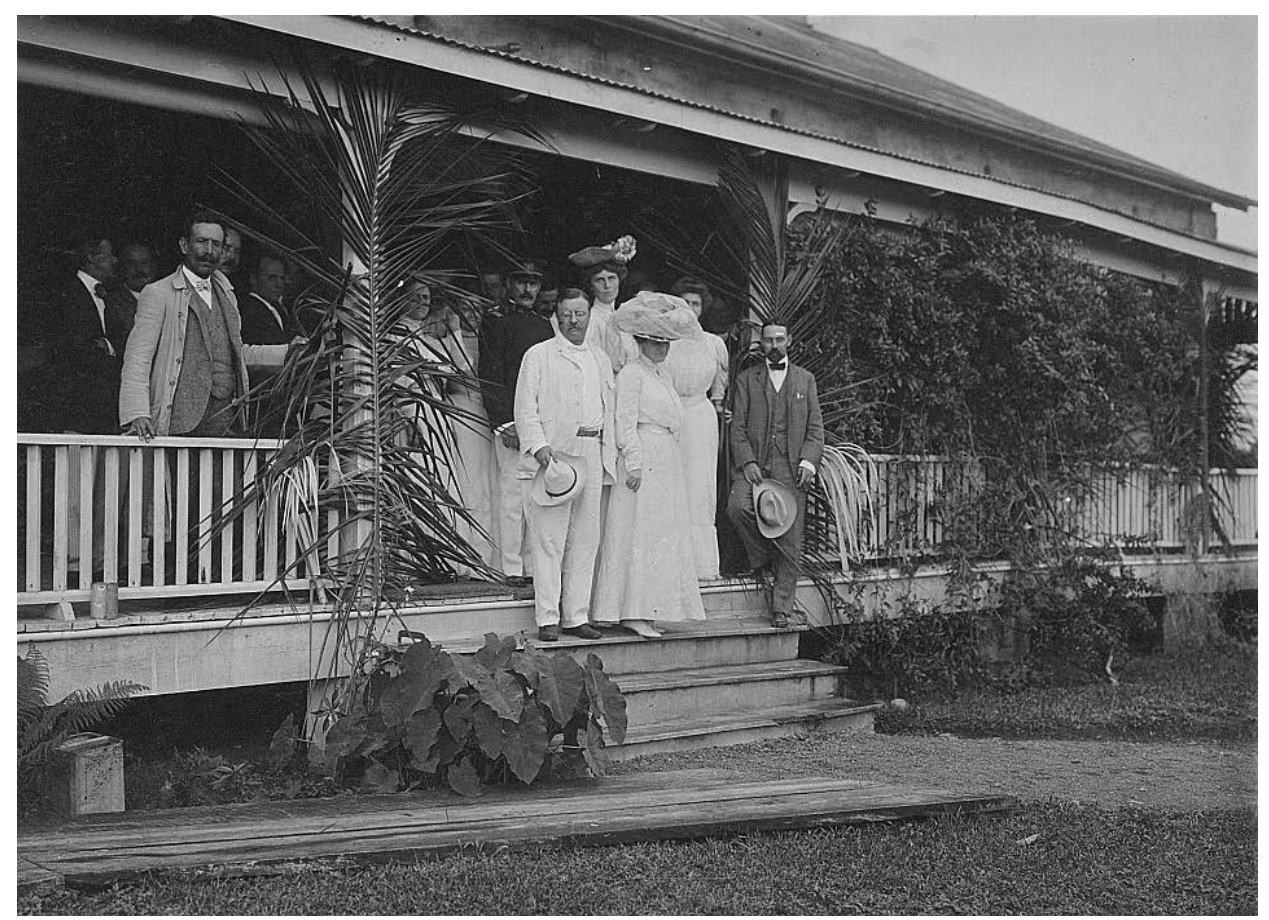

Figure 9. President Roosevelt visit Camp Henry U.S. Army the Post 1906 (Photo courtesy of the Library of Congress). LC-DIG-ppmsca-36399.

On February 24, 1919, Major Emmanuelli requested all buildings occupied by the Naval Stations to be returned to the Troops that were returning from the Canal Zone ${ }^{45}$. Lt Colonel Orval F. Townsend the Commander recommended that two companies of the Regiment be returned to Henry Barracks on or by May 24, 191946. On May 7, 1919 an authorization was declared for the construction of one-company size barracks in Henry Barracks at the cost of $\$ 12,750^{47}$. A recommendation was made to purchase land at Camp Henry. This land was north of the Reservation following a small ridge to the north and parallel to Route 1.

Noteworthy is the use of Stone houses found on the main routes from San Juan to the other large cities of the Island. They were called "Casa de los Camineros". For a period of time it was assumed that the people that maintained the routes used these houses. We found a letter dated May 20, 1919, where Col Townsend requests the use of the houses along the road from San Juan to Caguas as sleeping quarters for military personnel responsible for guarding the main roads. Figure 10 shows the ruin of a roadside house that served as sleeping quarters for soldiers guarding the roads. This was a common request at that time especially for Calvary Troops doing guard duty in the main roads ${ }^{48}$.

\footnotetext{
${ }^{45}$ Letter dated February 24, 1919 NARA 620 Barracks

${ }^{46} \mathrm{Ltr}$ from Lt Col. Orval P. Townsend dated March 25, 1919. NARA 680.3 Intended Resident La Puntilla, San Juan, Puerto Rico

${ }^{47}$ Letter from H.C.S. Neidtand, Adjutant General. NARA 320.3-Barracks and Quarters.

${ }^{48} \mathrm{Ltr}$ from the Commisioner of the Interior Mr Guillermo Esteves to Col O.P. Townsend-NARA 11-021-909, 620-Small House, near San Antonio Bridge.
} 


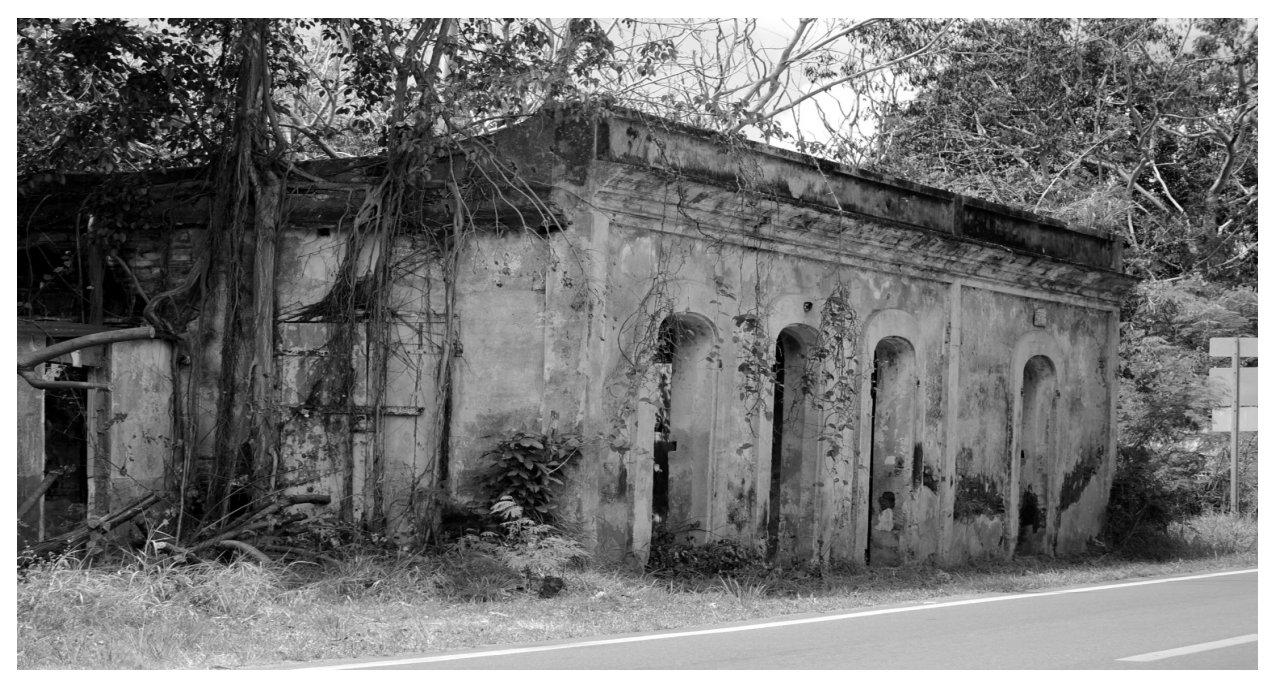

Figure 10. Ruins of a typical "Caminero" Road House used by the $65^{\text {th }}$ Inf. Calvary units while on guard duty.

In 1919, two companies ( $\mathrm{L}$ and $\mathrm{M}$ ) of the $3^{\text {rd }}$ Battalion returned to Henry Barracks. The Puerto Rican Regiment became the $65^{\text {th }}$ Infantry Regiment in $1920^{49}$. Upon their return to Henry Barracks, they occupied the barracks that were reconstructed. While Henry Barracks served as a fully operational Infantry training camp, many of the $2^{\text {nd }}$ Battalion troops deployed much time fighting in the Banana wars.

\section{The Impact of San Felipe on Henry Barracks}

On September 13, 1928, the Island of Puerto Rico was swept by a Hurricane named San Felipe. It carried sustained winds of over 160 miles per hour. Henry Barracks was destroyed ${ }^{50}$. The loss of a company size building that housed Co. M, $65^{\text {th }}$ Inf. damaged the infrastructure, Quarters, and government and personal properties. All the building made of wood and galvanized steel were damaged beyond repair. This included all the buildings in Hospital Hill: Hospital, barracks, a Kitchen and Mess Hall erected in 1900, and wooden buildings with galvanized steel roof constructed in 1901 and 1905, and a wooden building constructed in 1919, when the troops returned from the Canal Zone.

A Board of Officers was convened to determine the extent of damages to Henry Barracks. The Board met on September 14, 1928 and found that the greater majority of the buildings damaged or destroyed were wooden with galvanized steel. The Board recommended that all buildings of the sub-post of Henry Barracks be replaced with concrete or a suitable material other than wood ${ }^{51}$.

On July 5, 1929 replacements for the buildings lost in the Hurricane the previous

\footnotetext{
${ }^{49}$ US Army Center of Military History (12 March 2010). Linage and Honors. $65^{\text {th }}$ Infantry Regiment (The Bonriqueneers). Assessed on July 7, 2014 in

http://www.history.army.mil/html/forcestruc/lienages/branches/inf/oo65in.htm

${ }^{50}$ Cablegram \# 596. From San Juan, Puerto Rico to the Adjutant General, War Department from NAU 28September 18, 1928-NARA A.G. 600.913-Henry Bks. (9/17/28).

${ }^{51}$ Proceedings of a Board of Officers to determine the estimated damage and the cost of repair or replacement as a result of hurricane of September $13^{\text {th }}, 1928$. NARA-A-4.Box 913-Porto Rico 9-18-1928.
} 
year were completed. These included the commissary warehouse, two Kitchens, and Mess Halls located on the land used by the Navy. In addition fifty-eight pyramidal tents were completed by December 1928. An electric light system was completed by April 1929, and a gasoline shed was completed in June 1929. The hay shed, wagon sheds, and Q.M. Shops were completed by March 1929.

Shortly after arriving at Henry Barracks, Mr. Ford ${ }^{52}$, a civil engineer working for the Quartermaster (his Job Title was Construction Quartermaster ${ }^{53}$ ), was presented with several layouts. He was confronted with two problems: 1) the standard plans for construction of an Army Barracks could not be fit into the contour of the land (the reader will recall that this was the land was north of the Reservation following a small ridge) to the east of the existing post that had been previously purchased in 1919), and 2) the terrain was made of about eight inches of black soil and solid rock. Any excavation would have to be done through solid rock. A new layout was developed following the contour of the land, with an effort to keep the floors at approximately the same level ${ }^{54}$.

With the Civil Engineer (Constructing Quartermaster) there was a Quartermaster company assigned to Henry Barracks. While they stayed on temporary quarters on the South side of the Post they interacted with the workers and the soldiers from the $65^{\text {th }}$ Inf. They were called "Continentales".

Funds to construct a hospital were approved by the $70^{\text {th }}$ Congress on March 3, 1929, and the building was completed on May 9,1931 at a final cost of $\$ 35,000$. The hospital provided the facility for soldiers to be cared for near their battalion barracks; therefore, dependents did not have to travel to Fort Brooke for treatment.

In addition to the quarters for Officers and NCOs, on July 15, 1930 the construction of three barracks was begun. There were two one-company barracks (i.e., each accommodated one rifle company) and one two-company Infantry Barracks (i.e. accommodated the Battalion headquarters and a Machine Gun Company) ${ }^{55}$. The two-company barracks was completed on July 4, 1930. The two one-company quarters were completed on April 14, 1931.

By January 1932, the Constructing Quartermaster reported ${ }^{56}$ that twelve sets of Company Officers Quarters-one set of Field Officer's Quarters and six sets of noncommissioned Officer's Quarters-had been completed. These buildings were constructed to house officers and non-commissioned officers for one Battalion of the $65^{\text {th }}$ Infantry. These new housing quarters substituted the temporary shacks, since the previous quarters were destroyed by the Hurricane of 1928. Figure 11 depicts the buildings on a map of Henry Barracks.

\footnotetext{
${ }^{52}$ War Department Office of Chief Engineers, Construction Completion Reports NARA: NM-19-391, Box 121. ${ }^{53}$ War Department Office of Chief Engineers, Construction Completion Reports NARA: NM-19-391, Box 121. ${ }^{54}$ War Department Office of Chief Engineers, Construction Completion Reports NARA: NM-19-391, Box 121. ${ }^{55}$ There were two contracts issued for the construction of the Barracks: W-6578qm-2, and W-6578qm-58. Each building would be three-story type with a built-up roof. Each company had its own kitchen and mess-hall. They had a basement under the kitchen to serve as an armory and supply. The building were based on QMG Plans \# 621-727 and 621-720. NARA NM-19-Box 122.

${ }^{56}$ War Department Office of Chief Engineers. Construction Completion Reports 1917-1944. NARA NM-19391, Box 122.
} 


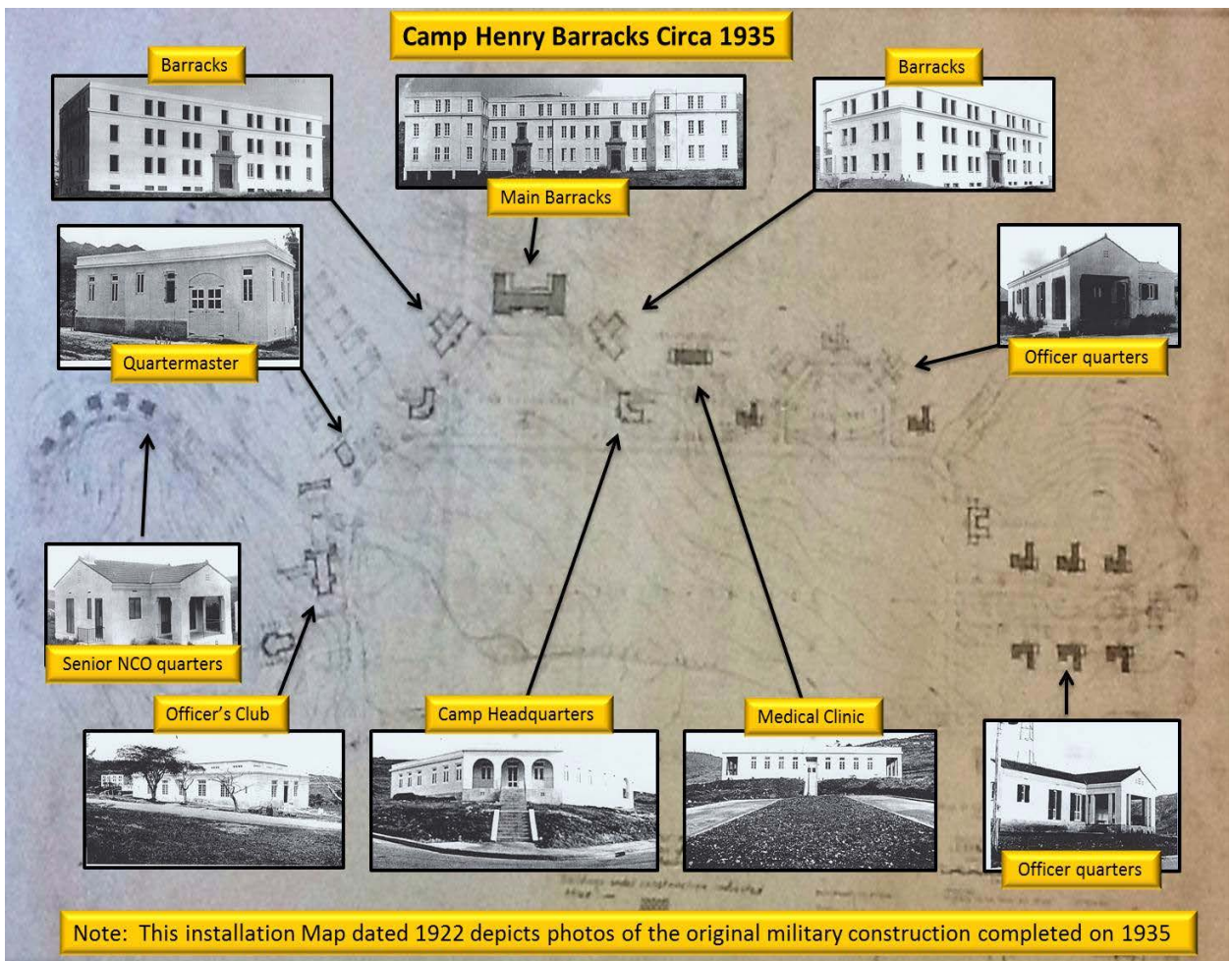

Figure 11. Map of Henry Barracks Army Post. NARA. Completion Report of Henry Barracks (1932). NARA NM-19-391, Box 122.

Another set of construction included a Post Exchange Building, Post Headquarters building, Guardhouse and Fire Station, Stable and Hayshed, Wagon Shed, Store House and Maintenance Building, and a Recreation hall ${ }^{57}$. Construction of these facilities was completed between March and September 1931. The Recreation Hall was completed on February $24,1932^{58}$.

On May 17, 1932, the construction of the installation's utilities was completed ${ }^{59}$. The following utilities were constructed: roads, walks, electric distribution system, a well, pumping stations, reservoir, water system, bridge, sewer system, sewage disposal plant, and grading and drainage.

In a Memorandum to the Chief of Staff initiated by Gen Douglas McArthur, Chief of Staff War Department dated October 28, 1933 with the subject being Disposition of Henry Barracks, Cayey, $\mathrm{PR}^{60}$, the guidance was as follows: "Relative to a transfer of Henry Barracks to Puerto Rico, the Commanding General, $2^{\text {nd }}$ Corps, states that Henry Barracks is required for military purposes, and therefore neither the proposed sale or transfer to the Puerto Rican Government can be favorably considered by the War

\footnotetext{
${ }^{57}$ Completion Report April 22, 1932. NARA-QM 600.92 C-NE (Henry Bks P.R.).

${ }^{58}$ These buildings were constructed through and appropriation for F.Y. Army Appropriation Act, Public Law NO. $278,71^{\text {st }}$ Congress approved May 28, 1930.

${ }^{59}$ Completion Report for Installations at Henry Barracks, Puerto Rico. NARA QM 600.92 C-NE (Henry Bks PR), May 17, 1932.

${ }^{60}$ Memorandum to the Chief of Staff (October 28, 1933). Disposition of Henry Barracks, Cayey, P.R. NARAA.G. 602 Henry Bks (9-26-33).
} 
Department. The costs for improvements in Henry Barracks were in excess for $\$ 620,000 " 61$.

Henry Barracks continued to be a sub-post of Fort Brooke until 1939 when Henry Barracks was declared a separate post ${ }^{62}$. Now Henry Barracks comprised of 264.54 acres to provide access to land where an infantry cadre could be trained in combat tactics.

By 1940 Henry Barracks had been developed into a complete military facility and fully functional infantry training ground. It housed the $2^{\text {nd }}$ and $3^{\text {rd }}$ Battalion of the $65^{\text {th }}$ Infantry Regiment and the reorganized $2^{\text {nd }}$ Battalion of the $25^{\text {th }}$ Field Artillery, and a company of the $2^{\text {nd }}$ Battalion 107 Quartermaster, called locally "Continentales"63. In this environment the members of the $65^{\text {th }}$ Infantry Battalion and the "Continentales" often interacted together on the post and in social and religious activities in the town of Cayey.

The Post consisted of approximately 190 structures including facilities for 1000-yard rifle range ammunition storage, waste water treatment, vehicle maintenance, sanitary landfill, and various other miscellaneous support facilities as well as housing and improvements such as roads and utility systems ${ }^{64}$. The facility had crossed Route 1 and went well into the Cayey mountain range where the "Pepe Hoyo" neighborhood is developed today ${ }^{65}$.

The map shows Henry Barracks in 1937 presented in Figure 12 highlights for the reader several areas of interest such as the Spanish Hospital/Camp Henry in 1901, the Motor Pool, and Cemetery, the three main barracks in the north part of the Post, the Headquarters building, and the hospital (where many children were born). The western part of the Post includes the three High Frequency towers constructed sometime after the 1920's and the control facility (large building by the track).

On 7 January 1943, the $65^{\text {th }}$ Infantry Regiment deployed to the Panama Canal Zone where it joined the Panama Canal Department's Mobile Force. In January 1944, the regiment embarked for New Orleans and then Fort Eustis, Virginia, in preparation for overseas deployment to North Africa. The $65^{\text {th }}$ Inf regiment arrived in April 1944. The $3^{\text {rd }}$ Battalion of the $65^{\text {th }}$ Inf was detached from the regiment and sent to Italy and then to Corsica to provide airfield security for Army Air Forces units. Near the end of 1944, the Battalion rejoined the regiment, and training was resumed with emphasis on village fighting.

In August 1944, Company C was detached from the regiment and flown to France to

${ }^{61}$ Letter from Brig Gen Guiney to the Quartermaster General re: cost of Henry Barracks. Nov 22, 1933. NARA-602-Puerto Rico-25796-13.

${ }^{62}$ General order No. 19 dated December 2, 1939, from the Headquarters of the Puerto Rican Department reads as follows: "Pursuant to authority contained in list endorsement, War Department, The Adjutant General's Office AG 323.341 (9-30-39) M (Ret)-C, October 30, 1939, the post of Henry Barracks, Cayey, Puerto Rico is designated as a separate post". (NARA).

${ }^{63}$ The $2^{\text {nd }}$ Battalion $25^{\text {th }}$ Field Artillery, the 107 QM Co. were housed in barracks located in the southern part of the Post, besides the airport.

${ }^{64}$ Army Corps of Engineering (2008). FUDS Property Name: Henry Barracks Military Reservation (Property Number 102 PR0979) County: Cayey City: Cayey Region: Puerto Rico Property Description. (Accessed from Internet on 7 July 2014).

${ }^{65} \mathrm{An}$ area of 1.94 acres was purchased in Barrio Montellano (now Pepe Hoyo) for water supply. It was about 1.4 miles from the Post up in the mountain range (now past Route 52). 


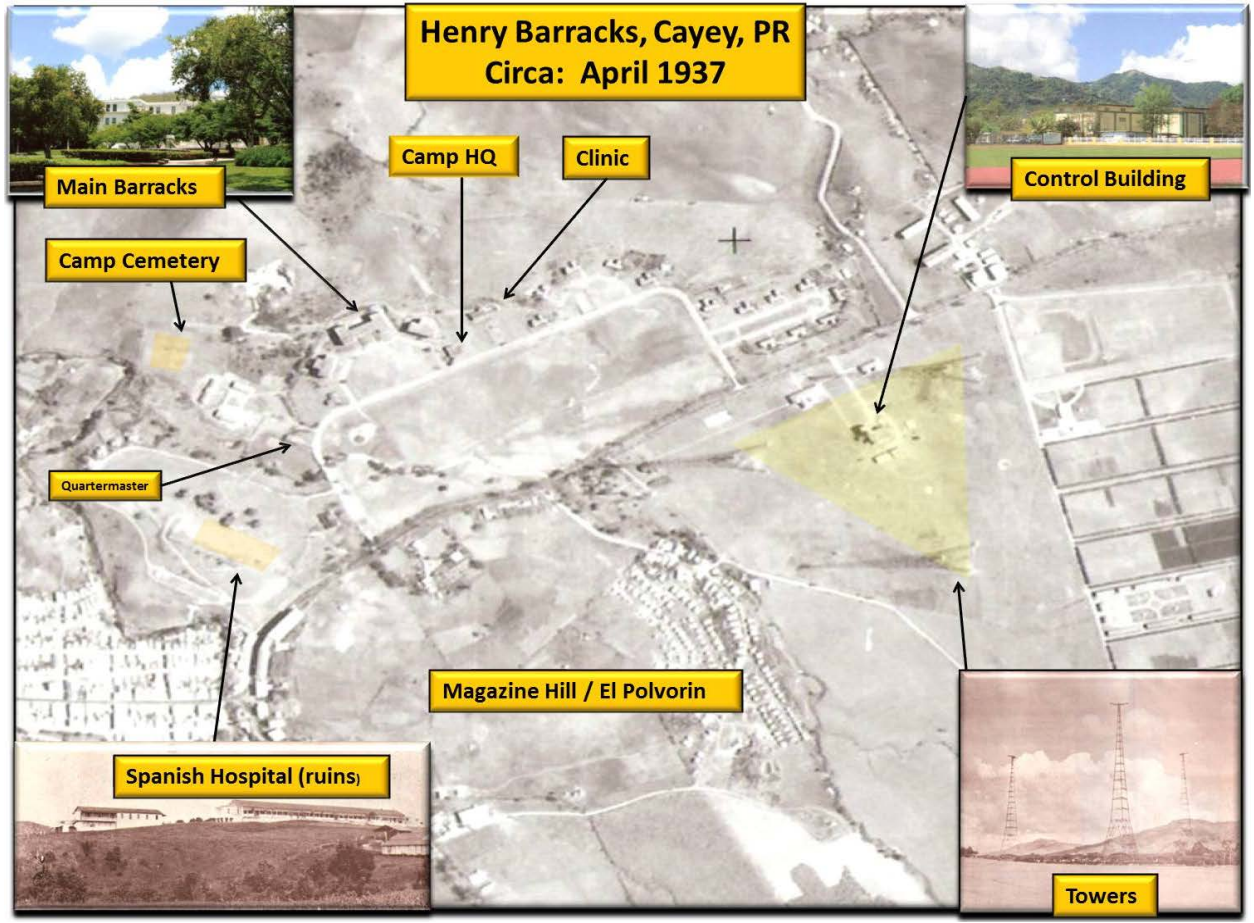

Figure 12. Aerial Photo of Henry Barracks 1937 (Map Section of NARA and pictures obtained from the photo collection of NARA).

take over the security of the Seventh Army Command Post ${ }^{66}$. In September 1944, the remainder of the regiment received orders to move to France and landed in Marseilles and Toulan early in October. The Battalion went into combat on 12 December 1944 at Peira Cava in the Maritime Alps of southern France.

In March 1945, the $65^{\text {th }}$ crossed the Rhine and remained in Germany as part of the Army of Occupation until October 1945, when it was ordered to Calais, France for the return home. The regiment arrived in Puerto Rico on 9 November 1945.

By 1950 Henry Barracks is preparing for war. Figure 13 shows an airport added that was long enough to support DC-3, C-45 and C-47. An aviation company can be seen in the plot of land south of the airport. By 1951, the $1^{\text {st }}$ Battalion 296 Inf Regiment-a National Guard unit sister to the $65^{\text {th }}$ Inf Regiment-was activated and assigned to Henry Barracks $^{67,68}$. The units assigned to Henry Barracks were Hq \& Hq Co., Company A, Company B, Company C, and Company D. This unit had its own motor pool. The unit and all ancillary resources were located in the southern part of Henry Barracks on the grounds recently vacated by the U.S. Navy. To accommodate this 1000 men plus four temporary barracks were constructed and 30 Pyramid Squad tents. Aerial Map 2 below

\footnotetext{
${ }^{66}$ Participation of Puerto Ricans in the Armed Services with Emphasis on World War I, World War II, and the Korean War, Headquarters Antilles Command, July 1965, p. 1. US Army Center of Military History, Fort McNair, Washington D.C.

${ }^{67}$ Units at Henry Barracks 1939-1962. NARA: 887540.

${ }^{68}$ The $92^{\text {nd }}$ Brigade, Fort Bragg, NC is comprised of the brigade headquarters, the $1^{\text {st }}$ Battalion, $65^{\text {th }}$ Infantry (Assault), the $192^{\text {nd }}$ Armored Troop E (Cavalry), the $192^{\text {nd }}$ Combat Support Battalion, the 1st Battalion, 295 ${ }^{\text {th }}$ Infantry (Assault), and the $1^{\text {st }}$ Battalion, $296^{\text {th }}$ Infantry (Assault).
} 


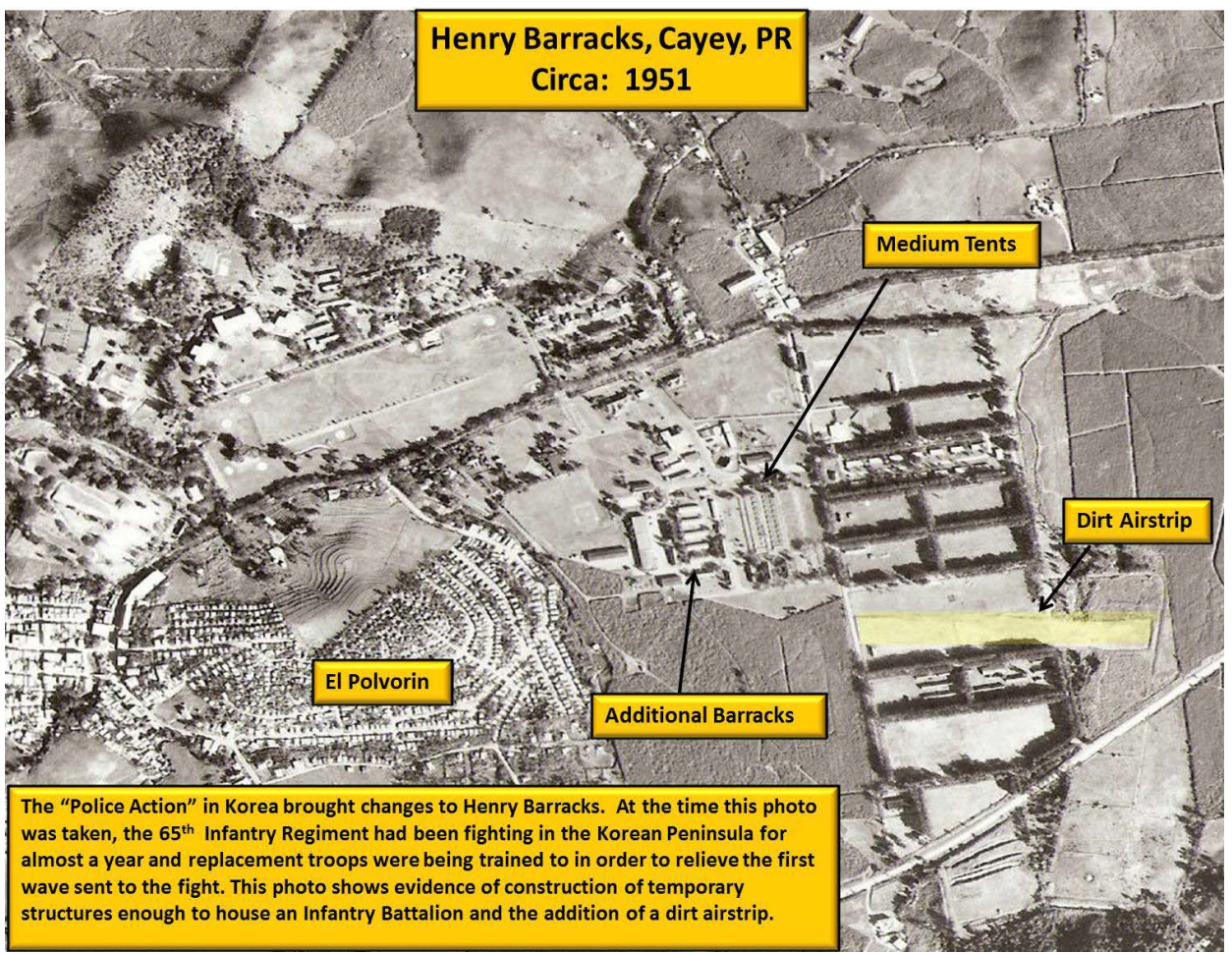

Figure 13. Aerial photo of Henry Barracks 1951- Preparing for war. Map obtained from the Map Collection NARA-887541.

presents the $294^{\text {th }}$ encampment area.

By 1955, the decision was made to de-activate Henry Barracks. It was passed from the control of the Army Corps of Engineers to the General Services Administration to dispose of the lands. The Puerto Rican National Guard Armory and the San Juan Geophysical Observatory are currently located on the site. The airfield has been closed. Reparto Montellano and Fullana military housing area have been constructed. In 1962 the bodies interred in the Henry Barracks cemetery were exhumed and transferred to the National Cemetery located in Bayamon Puerto Rico. The temporary building in front of the Commissary (currently the Office of the Superintendent of Schools) has been destroyed.

During the time between 1965 when the Post (Henry Barracks) closed to 1967 when the University of Puerto Rico began operation in the north part of the former Post, there were several activities of significance in the acreage comprising Henry Barracks ${ }^{69}$ (Figure 14).

\section{Re-Establishment of Henry Barracks to Civilian Use}

In January of 1965, Don Luis Muñoz Marin, the former governor, introduced a young

\footnotetext{
${ }^{69}$ In the current building housing the President of the University of Puerto Rico-Cayey the Caribbean Signal Agency was activated in 1961, later moved to Fort Allen in Juana Diaz. In the large building to the west, the National Guard had it Officer Training School in 1965 and 1966. It was later moved to Camp Santiago in Salinas. The golf course was used as a helicopter landing strip.
} 


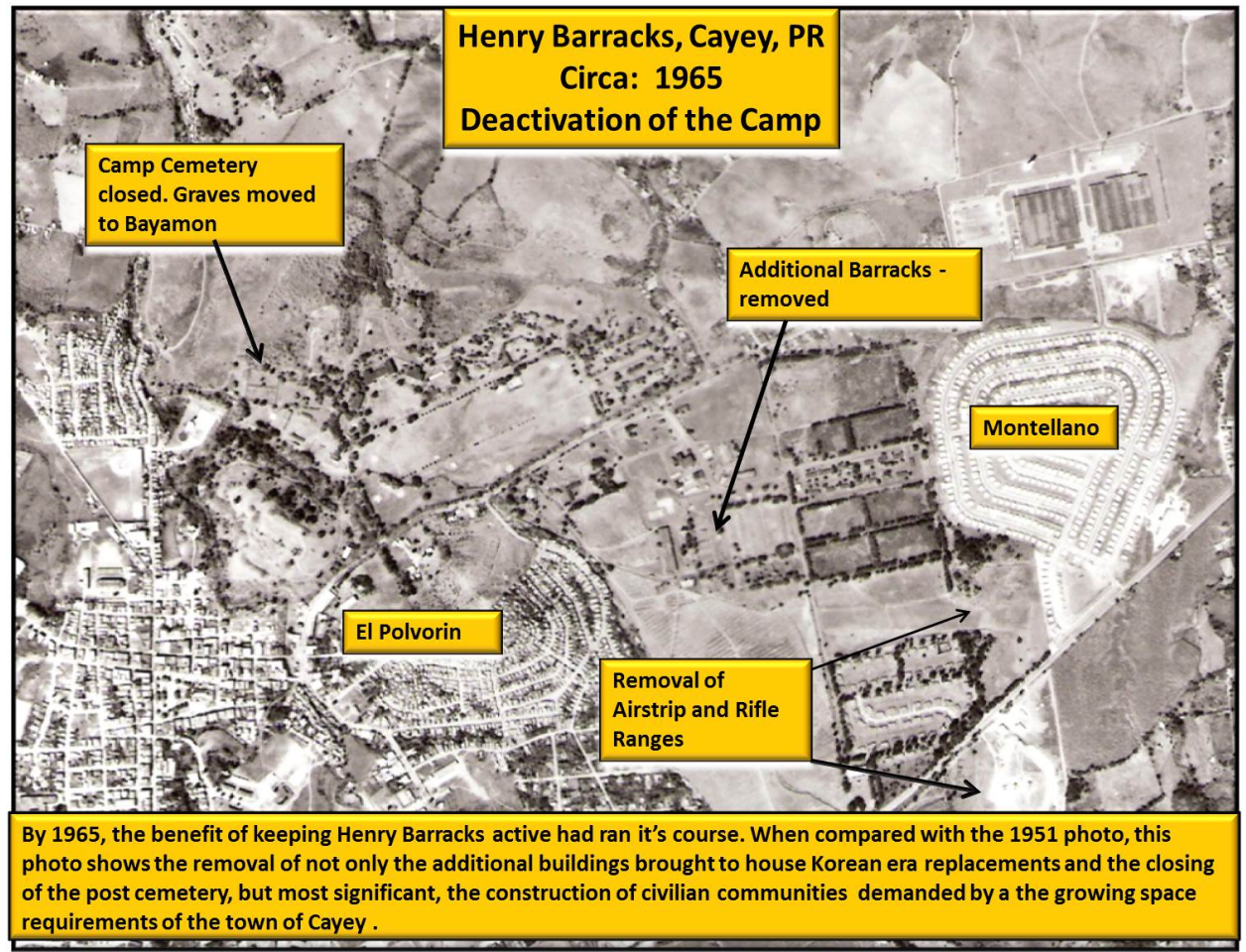

Figure 14. Aerial photo of Henry Barracks-By 1965 military activity had seized and the Post had closed down. Map collection NARA 887542.

American by the name of Peter Pond to twelve young leaders in Cayey ${ }^{70}$ and challenged them to develop a program that would keep the Youth of Puerto Rico civically occupied using the deserted ground of Henry Barracks. La YMCA Cuerpos de Paz de Puerto Rico was Rev. Peter L. Pond's conduit to programs for children that would assure inclusion, literacy, and foster well-being ${ }^{71}$. The report from this meeting as reported in El Mundo went like this: "the group meet with Governor Munoz Marin and his wife to discuss the possibilities of the program" According to Dr Juan A. Nogueras, one of the attendees to the meeting it was more like "marching orders". Don Luis wanted a program that fostered voluntarism, involved youth, and engaged the citizenry in community level projects.

The "program” became “VESPRA-Cuerpos de Paz de Puerto Rico". It would operate initially from the grounds of old Henry Barracks, now the University of Puerto Rico in Cayey. With funds from the Rockefeller Foundation and later the Office of Economic Opportunities, and using "creative problem solving" community members, university students, teachers, and young professionals would engage in a volunteers movement that fostered literacy, public health projects at the "barrio level", and would bring together youths into summer camps. The Fundación de Desarrollo Comunal took over a

\footnotetext{
${ }^{70}$ Rojas Laporte, B. (28 de Mayo de 1965). La YMCA abre campamento de adiestramiento para voluntarios de los Cuerpos de Paz de Puerto Rico. Periodico El Mundo. Suplemento Sabatino. P. 7-8).

${ }^{71}$ The YMCA, Cuerpos de Paz (Peace Corps), and Voluntarios En Servicio a Puerto Rico en Acción (VESPRA) (1965-1968) used the Administration Building, the swimming pool, the former golf course and three houses in the area formerly housing the Field Officers and families.
} 
housing area in the north-eastern part of former Henry Barracks, the objective was to train personnel that would volunteer in the Federal Community Development Agen$\mathrm{cy}^{72}$. By 1970, the Foundation for Community Development reported to its funding source that it had been successful in meeting its objectives. The most important achievement was the Poor People's Convention at the University of Puerto Rico in $1968^{73}$.

A third program of great impact to the community and the region was the Encampment for Citizenship $1966^{74}$. The program was initiated by the New York Ethical Society, the State Department of the United States, and former Governor Muñoz Marin. The objective was to bring Youth from diverse parts of the World and help them understand the concept of democracy in action. The summer of 1966 saw the greatest flow of ideas and intellectuals in what is now the center of the UPR-Cayey campus.

\section{Summary}

This paper presented the evolution of a place called Henry Barracks, Cayey from the Spanish rule and the outpost in Cayey, to the occupation of the only segregated Spanishspeaking Regiment in the United States Army, provided a historical overview of the role of the Henry Barracks Military Reservation in the economic development of the town of Cayey from 1898 to 1967 and its re-establishment as public lands. The history of this land has not been preserved. The University should make an effort to document the historical sites in its campus, and explain the impact of the former military installation in the economic and cultural impact in the region. At the very least the municipality of Cayey and the University of Puerto Rico should acknowledge with a historical marker the presence of the Spanish Encampment, and the visit of a sitting president of the United States (President Roosevelt) in 1906.

\section{References}

Army Corps of Engineering (2008). FUDS Property Name: Henry Barracks Military Reservation (Property Number I02PR0979). Cayey City: Puerto Rico Property Description.

Cayey Naval Station (1925). The Map and Photos Were Obtained from NARA-28677: 470.

Chief of Naval Operations to the Chief of the Bureau of Navigation (1922). Giving the Land of Magazine Hill to the Municipality of Cayey. NARA 12479-424: 24.

Completion Report (1932). NARA-QM 600.92 C-NE (Henry Bks, P.R.).

\footnotetext{
${ }^{72}$ With the opening of the University of Puerto Rico-Cayey in 1967, the Foundation for Community Development was moved to the housing located in the southeastern part of the Post formerly the first FHA project in Puerto Rico used for housing of dependents. They operated in these grounds until 1972. Thousands of people received training in community development and leadership during those years. Today the area is still called VESPRA Housing although used by the University.

${ }^{73}$ Ortiz, E. (December 10, 1968). A proposal for the continued development of the VESPRA Program of Puerto Rico. Cayey, P. R.: Fundacion de Desarrollo Comunal.

${ }^{74}$ The fifth Encampment for Citizenship took place in 1966 in the double Barracks, currently identified as the Miguel Melendez Munoz Building. The six-week encampment brought together 101 young leaders from 56 countries from all over the world to develop self-government and to perform community development projects. During the six-week project, one week was dedicated to a community activity. The one-week community project followed with one day of discussions created a climate where the participants became involved with their own home communities in New York, Connecticut, Montana, Puerto Rico, France, India, Kenya, Peru, and Guatemala.
} 
Daniels, J. (1916). Letter from Secretary of Navy to the Secretary of Treasury. NARA-28677:26.

Darrach, J. M. (1898). Descriptive Account of the Operations and Skirmishes about Guayama, Puerto Rico. Harper's Weekly, 1898, 942.

Duncan, W. (1910). Post and Reservation Map of Henry Barracks. PR Library of Congress, G-30-11-2-Mil Sta-PR.

Emerson, K. (2011). Maps of the Spanish American War: Puerto Rico, 1898. Puerto Rico Expedition. www.emersonkent.com

Executive Order \#3806 Ordering the Return of Magazine Hill to the Municipality of Cayey (1923). NARA-12479-424:27-3 P.

Hartzell, C. (1903). Register of Porto Rico for 1903. San Juan: Louis E. Tuzo Press and Co.

Hooper, S. C. (1922). Developments in High-Power Radio and Its Applications in the Services of the United States Navy. Radio Broadcasters Magazine, 1, 484-489.

Knock, T. J. (1992). To End All Wars: Woodrow Wilson and the Quest for a New World Order. Princeton, New Jersey: Princeton University Press.

Langley, L. D. (1983). United States Intervention in the Caribbean 1898-1934. Dover: Delaware: Scholarly Resources Inc.

Lopez, P. (1972). La historia de Cayey. Cayey: Departamento de Humanidades, Colegio Universitario de Cayey.

Muwsicant, I. (1998). Empire by Default (pp. 535-536). New York: Henry Holt \& Co.

Ortiz, E. (1968). A Proposal for the Continued Development of the VESPRA Program of Puerto Rico. Cayey: Fundacion de Desarrollo Comunal.

Parsons (2010). Henry Barracks Military Reservation-Cayey, Puerto Rico. Norcross, GA: US Army Corps of Engineers.

Participation of Puerto Ricans in the Armed Services with Emphasis on World War I, World War II, and the Korean War, Headquarters Antilles Command (1965). Washington DC: US Army Center of Military History.

Price, H. C., \& Lopez, C. M. (1915). Description of the Puerto Rico Regular Infantry. NARA Map Collection.

Rodriguez, V. (1897). Letter Written the Mayor of Cayey, to the Captain General of Puerto Rico. Biblioteca del Centro de Estudios de Puerto Rico.

Rojas Laporte, B. (1965). La YMCA abre campamento de adiestramiento para voluntarios de los Cuerpos de Paz de Puerto Rico (pp. 7-8). Periodico El Mundo Suplemento Sabatino.

Secretary of War (1915). Descripton of 59 Acres of Land and the the Magazine Hill Letter from the Secretary of War. NARA 12479-424: 15.

The Dramatic Ending of the War in Puerto Rico (1898). Teddy Roosevelt-RareNewspapers.com.

The Framework of Hemisphere Defense (2014).

http://www.history.army.mil/books/wwii/Guard-US/ch1.htm

Trask, D. F. (1981). The War with Spain in 1898. New York: MacMillan Publishing Inc.

US Army Center of Military History (2010). Linage and Honors: 65th Infantry Regiment (The Bonriqueneers).

http://www.history.army.mil/html/forcestruc/lienages/branches/inf/oo65in.htm

US Department of the Navy (1940) Building the Navy's Bases in World War II (Vol. 1., Chapter 18, p. 5). Washington DC: US Government Printing Service.

War Department Office of Chief Engineers (1944) Construction Completion Reports NARA: 
NM-19-391, Box 121.

War Department Office of Chief Engineers. (1946) Construction Completion Reports 1917-1944. NARA NM-19-391, Box 122.

Submit or recommend next manuscript to SCIRP and we will provide best service for you:

Accepting pre-submission inquiries through Email, Facebook, LinkedIn, Twitter, etc. A wide selection of journals (inclusive of 9 subjects, more than 200 journals)

Providing 24-hour high-quality service

User-friendly online submission system

Fair and swift peer-review system

Efficient typesetting and proofreading procedure

Display of the result of downloads and visits, as well as the number of cited articles

Maximum dissemination of your research work

Submit your manuscript at: http://papersubmission.scirp.org/

Or contact ahs@scirp.org 